\title{
Qualitative indicators of milk of Simmental and Holstein cows in different seasons of lactation
}

\author{
Aigerim Zhanuzakovna Khastayeva1 ${ }^{1}$, Venera Serikbayevna Zhamurova$^{1}$, Laura Asilbekovna Mamayeva1 (D), \\ Akylzhan Turalievish Kozhabergenov ${ }^{1}$, Nurlybek Zhanybekovich Karimov ${ }^{2}$ (D) and Karlygash Muratbekkyzy Muratbekova ${ }^{1}$ \\ 1. Department of Technology and Food Safety, Kazakh National Agrarian University, Abai Avenue, 8, Almaty 050010, \\ Kazakhstan; 2. Testing Center, LLP Kazakh Scientific Research Institute of Livestock and Fodder Production, Zhandosov \\ Street, 51, Almaty 050035, Kazakhstan. \\ Corresponding author: Nurlybek Zhanybekovich Karimov, e-mail: peksg55@gmail.com \\ Co-authors: AZK: gera_or@mail.ru, VSZ: zhamurova@yandex.ru, LAM: laura.mamayeva@kaznau.kz, \\ ATK: kozhabergenov79@mail.ru, KMM: kakasya88@yandex.ru \\ Received: 07-09-2020, Accepted: 17-02-2021, Published online: 21-04-2021
}

doi: www.doi.org/10.14202/vetworld.2021.956-963 How to cite this article: Khastayeva AZ, Zhamurova VS, Mamayeva LA, Kozhabergenov AT, Karimov NZ, Muratbekova KM (2021) Qualitative indicators of milk of Simmental and Holstein cows in different seasons of lactation, Veterinary World, 14(4): 956-963.

\begin{abstract}
Background and Aim: Milk producers need to ensure that their cows are producing high-quality, nutritional milk, which is influenced by the breed, age, nutrition, and health status of lactating animals. The aim of this study was to determine the effect of animal breed, season, and milk production on the physicochemical characteristics of milk and predicting the effect of these changes on the composition and quality of milk products.
\end{abstract}

Materials and Methods: In total, 80 milk samples (40 Simmental and 40 Holstein) were analyzed from LLP "Kirova" of Pavlodar region (Simmental breed) and JSC "Astana-Onim" of Akmola region (Holstein breed) in the Republic of Kazakhstan. The physicochemical parameters, including fatty acid (FA) content, were studied.

Results: The Simmental cows had the lowest mass fraction of fat in the spring at $3.94 \%$ and the highest fat content in the winter at $4.09 \%$, which was the overall highest fat content measured in both breeds $(\mathrm{p}<0.001)$. The lowest protein in the Simmentals was also measured in the spring. The Holstein cows had the highest fat content at $3.8 \%$ and the highest protein content at $3.3 \%$ in autumn.

Conclusion: It was found that the season and breed significantly affected the physicochemical parameters and the FA contents in cow milk. The superiority of the Simmental cows over the Holstein cows throughout the year was statistically significant.

Keywords: cow's milk, fatty acid composition, Holstein, season, Simmental breed.

\section{Introduction}

Milk is a biological fluid with a high nutritional value. Its constituents include, for example, water, milk fat, proteins, lactose, and minerals. Since the quality of dairy products depends largely on the composition of raw bulk milk, factors responsible for changes to the composition and physicochemical properties of raw milk are of paramount importance. The main factors influencing the composition of milk are season, lactation stage, feeding, milking interval, breed, and age of the dairy cow [1]. The effect of seasonal fluctuations on milk yield (MY) and milk composition has been widely researched [1-3]. Milk components vary based on milking time, DIM, season age, and health of the cow $[4,5]$.

Milk protein is an important indicator of milk quality. The protein content in milk reflects whether

Copyright: Khastayeva, et al. Open Access. This article is distributed under the terms of the Creative Commons Attribution 4.0 International License (http://creativecommons.org/licenses/ by/4.0/), which permits unrestricted use, distribution, and reproduction in any medium, provided you give appropriate credit to the original author(s) and the source, provide a link to the Creative Commons license, and indicate if changes were made. The Creative Commons Public Domain Dedication waiver (http:// creativecommons.org/publicdomain/zero/1.0/) applies to the data made available in this article, unless otherwise stated. the cow is supplied with energy and is an energy barometer for the herd. Specifically, the amount of protein in milk depends on whether enough energy is available to the rumen microbes that synthesize microbial protein [6]. Milk fat is a complex consisting of simple lipids (triglycerides, diglycerides, and monoglycerides), complex lipids (phospholipids, lecithin, cephalin, and sphingomyelin), derivatives of lipids (free fatty acids [FA]), and substances associated with fat (sterols, cholesterol, fat-soluble Vitamins A, E, D, and $\mathrm{K}$, and carotenoids) [7].

The secretion of milk fat and the composition of lactic FA are of great interest to human nutrition; their modification in dairy cows through dietary manipulations has attracted considerable research attention [8]. Milk fat contains more than 400 FAs, which occur partly from the synthesis of the breast (almost 50\%), partly from the diet, which is affected by the process of rubenbiohydrogenation, and due to the immobilization of animal fat deposits [9]. Some FA classes, such as branched-chain FA and cis-and trans-isomers 18:1, 18:2, and 18:3, are associated with rumen activity [10-12], while other FA classes, such as de novo FA, and classes with 18 carbon chains are also associated with energy exchange [12-14]. Thus, 
since the FA profile of milk can be viewed as a trace of the cow's nutrition and metabolism, an analysis of MY variability and the FA profile can be used to draw conclusions regarding various farming or forage systems, herds, or even factors that influence the health status of the cows.

Milk quality is also assessed using sanitary and hygienic indicators that can be used to judge the freshness of milk (titrated acidity) and the well-being of the farm (diseases), since milk from sick cows has increased bacterial contents and somatic cells. In addition, bacterial contamination can be used to assess the technology of milk production and compliance with veterinary and sanitary rules for milking animals [15]. Somatic cell counts (SCCs) are an important parameter in udder health, since somatic cells are involved in protecting the mammary glands from infection as part of the animal's immune system. SCC in milk is affected by many factors, including species, level of milk production, lactation stage, management methods, and a variety of individual and environmental factors [16].

The aim of this study was to determine the effect of animal breed, season, and milk production on the physicochemical characteristics of milk and predicting the effect of these changes on the composition and quality of milk products.

\section{Materials and Methods}

\section{Ethical approval and Informed consent}

No ethical approval was required; however, during the collection of samples, verbal permission was taken from the farm owners and farm workers.

\section{Study area and period}

Milk was obtained from LLP "Kirova" of Pavlodar region (Simmental breed) and JSC "AstanaOnim" of Akmola region (Holstein breed) of the Republic of Kazakhstan. Samples were obtained from June 2017 to May 2018. The physicochemical characteristics of milk were assessed at the laboratory of LLC Kazakh Research Institute of Livestock Breeding and Fodder Production using a high-performance, fully-automatic milk analyzer (MilkoScan $\mathrm{FT}+$; Fossomatic $\mathrm{FT}+$ ).

\section{Animals}

The composition and process properties of milk were studied using 80 milk samples from 40 Simmental and 40 Holstein cows. The cows at the dairy farm were kept loose on a natural pasture. Grazing of farm animals was carried out on fenced pastures. They had water ad libitum.

\section{Experimental design}

The samples were prepared and FA compositions were determined in accordance with the State Standard 32915-2014 [17]. FA was determined using a gas chromatograph GC Shimadzu-2010 Plus with a flame ionization detector and a capillary column Agilent J\&W Columns GP-Sii 88 for FAME with the dimensions of $100 \mathrm{~m} \times 0.25 \mathrm{~mm} \times 0.2 \mu \mathrm{L}$. Nitrogen, hydrogen, and air were supplied to the detector from the gas flow regulator; the maximum detector temperature was $260^{\circ} \mathrm{C}$ with temperature settings at $100^{\circ} \mathrm{C}$ for $5 \mathrm{~min}$, up to $210^{\circ} \mathrm{C}$ for $8 \mathrm{~min}$ at the speed of $4^{\circ} \mathrm{C} / \mathrm{min}$, up to $240^{\circ} \mathrm{C}$ for $25 \mathrm{~min}$ at the speed of $10^{\circ} \mathrm{C} / \mathrm{min}$; the volume of the injected sample was $1 \mu \mathrm{L}$. The splitting flow was $1 / 40$.

\section{Statistical analysis}

The obtained data were processed through variation statistics using the Statistica software package for Windows version 6.0 (Stat Soft Inc., USA).

\section{Results}

It should be noted that the variation of the main breeding characteristics generally obeys the laws of normal distribution $(\mathrm{p}<0.05)$ : The fat content in milk (in Holsteins $\chi_{\text {emp }}^{2}=0.138$ at $\chi_{\text {theor }}^{2} 0.95=3.84$; in Simmentals $\chi_{\text {emp }}^{2}=2.711$ at $\chi_{\text {theor } 0.95}^{2}=5.99$ ), the protein content in milk (in Holsteins $\chi_{\text {emp }}^{2}=0.773$ in Simmentals $\chi_{\text {emp }}^{2}=1.196$ ), linoleic FA (in Holsteins $\chi_{e m p}^{2}=0.146$ in Simmentals $\chi_{\text {emp }}^{2}=1.889$ ), and so on. According to some signs (for example, a linolenic (omega 3, somatic cell content), an asymmetric distribution is observed.

The obtained physicochemical and microbiological milk quality indicators and their statistical characteristics for a period of 305 lactation days are presented in Table-1. On average, the Simmental milk contained $3.39 \%$ protein and $4.02 \%$ fat. The Holstein milk contained an average $3.22 \%$ protein and $3.72 \%$ fat. The differences in fat content between the two breeds were statistically significant, with Simmental milk having higher fat contents in summer and winter $(p<0.001$ and $p<0.05$, respectively), while the other periods of the year were random $(p>0.05)$.

A higher content of somatic cells in the Simmental milk was measured during all periods of lactation: $330.57 \times 10^{3}$ cells $/ \mathrm{cm}^{3} ; 384.24 \times 10^{3}$ cells $/ \mathrm{cm}^{3} ; 405.81$ $\times 10^{3} \mathrm{cells} / \mathrm{cm}^{3}$; and $410.98 \times 10^{3} \mathrm{cells} / \mathrm{cm}^{3}$. According to European standards, cow milk is allowed to have 250 thousand somatic cells per $1 \mathrm{~cm}^{3}$. According to the Technical Regulations of the Customs Union 033/2013 "On the Safety of Milk and Dairy Products," cow milk is allowed to have 750 thousand somatic cells per $1 \mathrm{~cm}^{3}$. If the number of somatic cells exceeds this value, then the milk is considered to be of insufficient quality for use in high-quality dairy products due to the milk's corresponding low casein, milk sugar, calcium, magnesium, and phosphorus contents [18]. From the data presented in Table-1, we can notice very high lability of the somatic cell content in all seasons of the year: The coefficient of variability varies from $65.11 \%$ (Simmental) to $178.13 \%$ (Holstein). A relatively low level was observed in the autumn period. 
Table-1: Physicochemical and microbiological indicators of milk by season.

\begin{tabular}{|c|c|c|c|c|c|}
\hline $\begin{array}{l}\text { Biometric } \\
\text { indicators }\end{array}$ & $\begin{array}{l}\text { Mass fraction } \\
\text { of fat, } \%\end{array}$ & $\begin{array}{l}\text { Mass fraction } \\
\text { of protein, } \%\end{array}$ & $\begin{array}{l}\text { The content of somatic } \\
\text { cells, thousand per } 1 \mathbf{c m}^{3}\end{array}$ & Acidity, ${ }^{\circ} \mathbf{T}$ & Density, $\mathrm{g} / \mathrm{cm}^{3}$ \\
\hline \multicolumn{6}{|c|}{ Spring } \\
\hline \multicolumn{6}{|c|}{ Holstein $(n=40)$} \\
\hline $\bar{x} \pm m_{\bar{x}}$ & $3.70 \pm 0.04$ & $3.18 \pm 0.05$ & $260.11 \pm 45.40$ & $16.80 \pm 16.8$ & $1027.00 \pm 0.15$ \\
\hline$\sigma$ & 0.26 & 0.30 & 287.17 & 0.79 & 0.96 \\
\hline & 7.13 & 9.58 & 110.40 & 4.71 & 0.09 \\
\hline \multicolumn{6}{|c|}{ Simmental $(n=40)$} \\
\hline $\bar{x} \pm m_{\bar{x}}$ & $3.94 \pm 0.06$ & $3.32 \pm 0.07$ & $330.57 \pm 78.19$ & $16.80 \pm 0.11$ & $1028.00 \pm 0.19$ \\
\hline$\sigma$ & 0.37 & 0.43 & 494.54 & 0.69 & 1.22 \\
\hline$C v$ & 9.27 & 12.96 & 149.60 & 4.10 & 0.12 \\
\hline$d_{\bar{x}_{1}-\bar{x}_{2}}$ & 0.24 & 0.14 & 70.46 & 0 & 1 \\
\hline$t_{d} / p$ & $3.33 /<0.01$ & $1.63 />0.05$ & $0.78 />0.05$ & $0.00 />0.05$ & $4.13 /<0.001$ \\
\hline \multicolumn{6}{|c|}{ Summer } \\
\hline \multicolumn{6}{|c|}{ Holstein $(n=0)$} \\
\hline $\bar{x} \pm m_{\bar{x}}$ & $3.73 \pm 0.05$ & $3.17 \pm 0.05$ & $167.96 \pm 24.06$ & $18.00 \pm 0.08$ & $1028.00 \pm 0.21$ \\
\hline$\sigma$ & 0.30 & 0.35 & 152.15 & 0.51 & 1.32 \\
\hline $\mathrm{CV}$ & 7.97 & 10.89 & 90.59 & 2.81 & 0.13 \\
\hline \multicolumn{6}{|c|}{ Simmental $(n=40)$} \\
\hline \multicolumn{6}{|c|}{$\bar{x} \pm m_{\bar{x}}$} \\
\hline$\sigma$ & 0.27 & 0.20 & 460.48 & 0.82 & 1.15 \\
\hline$C v$ & 6.82 & 5.75 & 119.84 & 4.80 & 0.11 \\
\hline \multicolumn{6}{|l|}{$d_{\bar{x}_{1}-\bar{x}_{2}}$} \\
\hline$t_{d} / p$ & $4.06 /<0.001$ & $4.80 /<0.001$ & $2.82 /<0.05$ & $6.55 /<0.001$ & $0.00 />0.05$ \\
\hline \multicolumn{6}{|c|}{ Autumn } \\
\hline \multicolumn{6}{|c|}{ Holstein $(n=40)$} \\
\hline $\bar{x} \pm m_{\bar{x}}$ & $3.80 \pm 0.04$ & $3.30 \pm 0.06$ & $282.77 \pm 31.36$ & $17.00 \pm 0.15$ & $1027.00 \pm 0.14$ \\
\hline$\sigma$ & 0.26 & 0.38 & 198.31 & 0.92 & 0.88 \\
\hline$C v$ & 6.96 & 11.47 & 70.13 & 5.40 & 0.09 \\
\hline \multicolumn{6}{|c|}{ Simmental $(n=40)$} \\
\hline $\bar{x} \pm m_{\bar{x}}$ & $4.04 \pm 0.04$ & $3.39 \pm 0.02$ & $405.81 \pm 41.78$ & $17.00 \pm 0.12$ & $1029.00 \pm 0.16$ \\
\hline$\sigma$ & 0.24 & 0.14 & 264.21 & 0.78 & 0.99 \\
\hline $\mathrm{CV}$ & 5.89 & 4.11 & 65.11 & 4.61 & 0.10 \\
\hline \multicolumn{6}{|l|}{$d_{\bar{x}_{1}-\bar{x}_{2}}$} \\
\hline$t_{d} / p$ & $4.24 /<0.001$ & $1.42 />0.05$ & $2.36 /<0.05$ & $0.00 />0.05$ & $9.41 /<0.001$ \\
\hline \multicolumn{6}{|c|}{ Winter } \\
\hline \multicolumn{6}{|c|}{ Holstein $(n=40)$} \\
\hline $\bar{x} \pm m_{\bar{x}}$ & $3.64 \pm 0.06$ & $3.22 \pm 0.05$ & $343.92 \pm 96.86$ & $16.90 \pm 0.13$ & $1027.00 \pm 0.14$ \\
\hline$\sigma$ & 0.37 & 0.32 & 612.61 & 0.84 & 0.88 \\
\hline$C v$ & 10.03 & 9.81 & 178.13 & 4.98 & 0.09 \\
\hline \multicolumn{6}{|c|}{ Simmental $(n=40)$} \\
\hline $\bar{x} \pm m_{\bar{x}}$ & $4.09 \pm 0.08$ & $3.41 \pm 0.07$ & $410.98 \pm 90.74$ & $16.70 \pm 0.10$ & $1027.00 \pm 0.16$ \\
\hline$\sigma$ & 0.50 & 0.45 & 573.87 & 0.65 & 0.99 \\
\hline $\mathrm{Cv}$ & 12.25 & 13.10 & 139.64 & 3.88 & 0.10 \\
\hline$d_{\bar{x}_{1}-\bar{x}_{2}}$ & 0.45 & 0.19 & 67.06 & 0.2 & 0 \\
\hline$t_{d} / p$ & $4.50 /<0.001$ & $2.21 /<0.05$ & $0.51 />0.05$ & $1.22 />0.05$ & $0.00 />0.05$ \\
\hline
\end{tabular}

The seasonal variability of the other physical and chemical parameters was within the normal range.
Milk acidity was higher in the Holstein cows $(\mathrm{p}<0.05)$. It should be noted that other seasons and years in both 
breeds did not display significant differences. The mass fraction of dry skimmed milk substances in Simmental cows in the spring, summer, autumn, and winter periods was $8.57 \% ; 8.62 \% ; 8.7 \%$; and $8.71 \%$, and $8.56 \% ; 8.88 \% ; 8.64 \%$; and $8.48 \%$ in Holstein cows, respectively.

The results of the two-factor analysis of variance are given in Table-2, which shows the proportion of influence that the studied factors (breed and season) had separately, and their combined effect on the physicochemical and microbiological milk parameters. Breed had a highly reliable influence on all studied indicators, except for milk acidity, but season had only a random effect (except for milk density). The ratio of factorial variance to total variances was from 7.04 (somatic cell content) to $30.69 \%$ (milk density), in all cases, $\mathrm{F}_{e m p}>\mathrm{F}_{s t}$ (for somatic cell content: $\mathrm{p}<0.01$; for the rest: $\mathrm{p}<0.001$ ).

The seasonal dynamics of mass fractions of the 16 main FA in the milk fat is given in Tables- 3 and 4. Some FA were not included in the list, since their relative peak areas exceeded $0.1 \%$. As expected, Saturated FA (SFA) represented the most common class followed by monounsaturated FA (MUFA) and polyunsaturated FA (PUFA). The most common FA in both groups were $\mathrm{C} 16: 0$, which is the sum of the isomers C18:1, C18:0, and C14:0. No statistical difference in the concentrations of these compounds was observed between the two studied breeds. In addition, short- and medium-chain SFA, such as C4:0, C6:0, C8:0, C10:0, and $\mathrm{C} 12: 0$, were present at the expected levels. In the spring and summer, relatively high butyric acid $\mathrm{C} 4: 0$ content was noted in the milk of both breeds, which is characteristic of milk fat, and is involved in the flavor creation of dairy products.

Among MUFA, the $\mathrm{C} 18: 1$ isomers were the main components. In general, the remaining percentage of monounsaturated FA in the total amount of milk fat in the Simmental breed was $2.96 \% ; 3.47 \% ; 4.06 \%$; and $3.16 \%$; and $3.8 \% ; 3.51 \% ; 3.64 \%$; and $3.5 \%$ in the Holstein breed. All of which were significantly higher in the milk from the Holstein cows. PUFA in the Simmental breed was 3.46\%; 3.55\%; 3.13\%; and $4.52 \%$ and in the Holstein breed was $5.13 \% ; 4.74 \%$; $4.61 \%$; and $3.71 \%$ of the total amount of FA. In both groups of milk, C18:2n-6 was the predominant compound. The percentage of $\dot{\omega}-3$ PUFA was higher in the samples from the Simmental breed $(1.06 \%$ and $1.17 \%$ vs. $0.97 \%$ and $0.8 \%$ ) in the summer and in the winter compared to the Holstein breed; however, the percentage of $\dot{\omega}-3$ PUFA in the spring and autumn periods in the Holstein breed was $1.29 \%$ and $1.01 \%$ versus $0.42 \%$ and $0.67 \%$. The percentage of $\dot{\omega}-6$ PUFA (3.84\%; $3.84 \%$; and $3.6 \%$ vs. $3.04 \%$; $2.49 \%$; and $2.46 \%$ ) in the spring, summer, and the autumn was higher in the Holstein breed than the Simmental breed.

A noticeable interbreed difference was observed in the C10:1, C12:0, C16:1, C18:1, and C18:3 FA contents: The first two-three acids were higher in the Holstein cows, but C18:1 was higher in the Simmental cows (except for in the autumn). Interbreed differences in the FA C6:0, C10:0, C14:0, C16:1, and C18:3 were also statistically significant, except for some seasons of the year (mainly the summer). It is noteworthy that the mass fraction of $\mathrm{C} 6: 0, \mathrm{C} 8: 0$, and $\mathrm{C} 10: 0 \mathrm{FA}$ in the spring-summer and winter periods was higher

Table-2: Influence of the breed and season on the physicochemical and microbiological parameters of milk.

\begin{tabular}{|c|c|c|c|c|c|c|}
\hline & A (breed) & B (season of the year) & $A B$ (the joint effect of) & $x$ & $z$ & $y$ \\
\hline \multicolumn{7}{|c|}{ Fat content in milk } \\
\hline$D$ & 105 & 8.71 & 13.46 & 126.8 & 527.4 & 654.2 \\
\hline$\eta$ & 0.16 & 0.01 & 0.02 & 0.19 & 0.81 & 1.00 \\
\hline$\sigma^{2}$ & 104.65 & 2.90 & 4.49 & 18.12 & 1.69 & 2.05 \\
\hline$F_{e m p}$ & $61.91 * * *$ & 1.72 & $2.65^{*}$ & $10.72 * * *$ & - & - \\
\hline \multicolumn{7}{|c|}{ Protein content in milk } \\
\hline$D$ & 66.613 & 10.26 & 11.11 & 88.0 & 882.9 & 970.9 \\
\hline$\eta$ & 0.07 & 0.01 & 0.01 & 0.09 & 0.91 & 1.00 \\
\hline$\sigma^{2}$ & 66.61 & 3.42 & 3.70 & 12.57 & 2.83 & 3.04 \\
\hline$F_{\text {emp }}$ & $23.54 * * *$ & 1.21 & 1.31 & $4.44 * * *$ & - & - \\
\hline \multicolumn{7}{|c|}{ The content of somatic cells, thousand per $1 \mathrm{~cm}^{3}$} \\
\hline$D$ & 8.72 & 2.99 & 6.09 & 17.8 & 235.1 & 252.9 \\
\hline$\eta$ & 0.03 & 0.01 & 0.02 & 0.07 & 0.93 & 1.00 \\
\hline$\sigma^{2}$ & 8.7 & 1.00 & 2.03 & 2.54 & 0.76 & 0.80 \\
\hline $\mathrm{F}_{\text {emp }}$ & $11.5^{* * *}$ & 1.31 & $2.67 *$ & $3.34 * *$ & - & - \\
\hline \multicolumn{7}{|c|}{ Density, $2 / \mathrm{CM}^{3}$} \\
\hline$D$ & 45.00 & 55.00 & 55.00 & 155.0 & 350.0 & 505.0 \\
\hline$\eta$ & 0.09 & 0.11 & 0.11 & 0.31 & 0.69 & 1.00 \\
\hline$\sigma^{2}$ & 45.0 & 18.33 & 18.33 & 22.14 & 1.12 & 1.58 \\
\hline $\mathrm{F}_{\mathrm{emp}}$ & $40.1 * * *$ & $16.34 * * *$ & $16.34 * * *$ & $19.74 * * *$ & - & - \\
\hline \multicolumn{7}{|c|}{ Acidity, ${ }^{\circ} T$} \\
\hline$D$ & 0.15 & 3.01 & 0.66 & 3.8 & 182.2 & 186.0 \\
\hline$\eta$ & 0.001 & 0.02 & 0.004 & 0.02 & 0.98 & 1.00 \\
\hline$\sigma^{2}$ & 0.2 & 1.00 & 0.22 & 0.55 & 0.58 & 0.58 \\
\hline$F_{e m p}$ & 0.3 & 1.72 & 0.38 & 0.94 & - & - \\
\hline
\end{tabular}


Table-3: Fatty acid composition of milk in the spring-summer period.

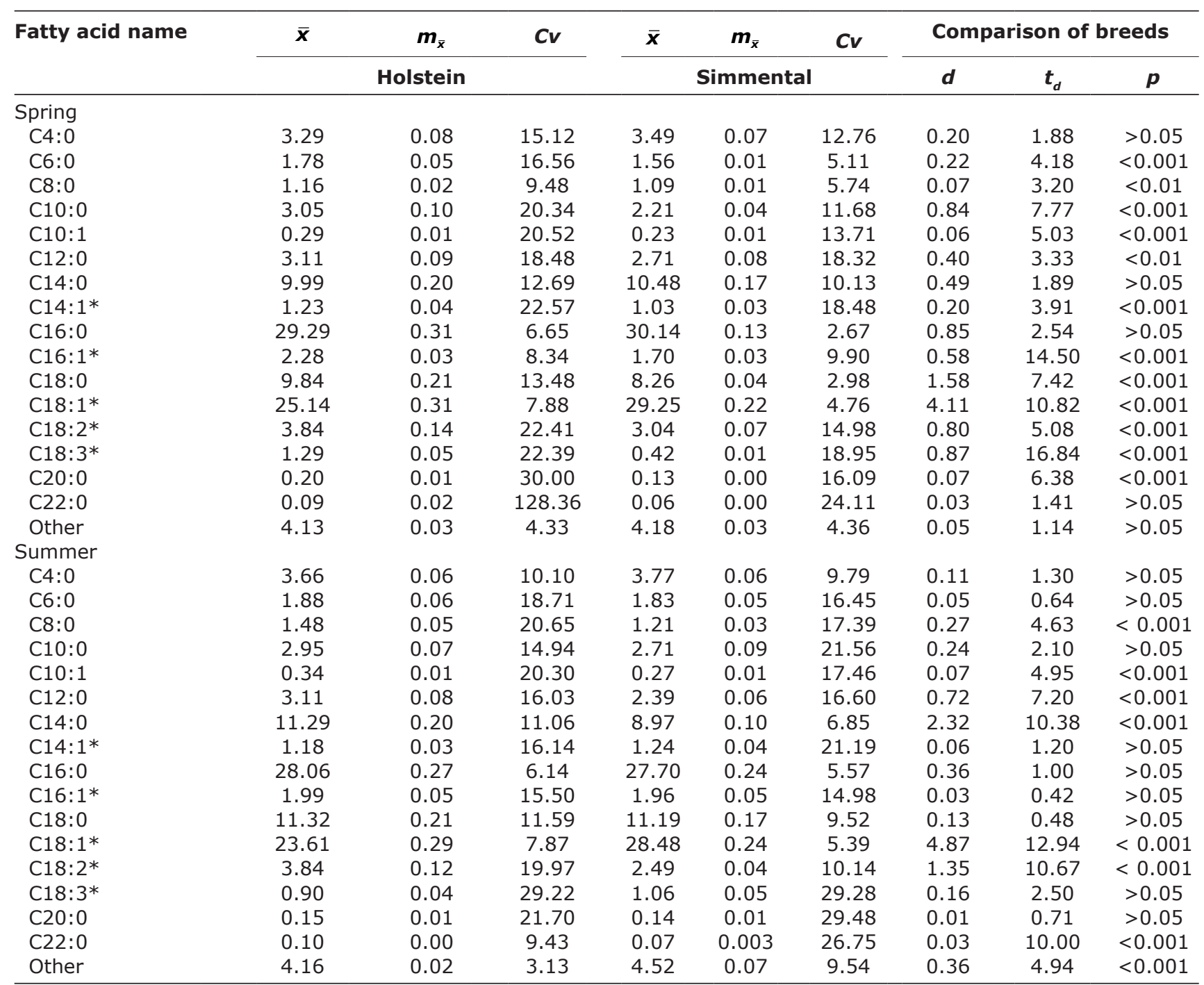

*The calculation is based on the sum of the isomers. by $v=40+40-2=78 t_{s t}=1.98(p=0.05)-2.63(p=0.01)-3.39$ $(p=0.001)$

in the Holstein cows, but that the autumn period was higher in the Simmental cows $(\mathrm{p}<0.001)$. There were no noticeable interbreed differences in the sum of the isomers C4:0, C16:0, C20:0, and $\mathrm{C} 22: 0$ ( $\mathrm{p}>0.05)$. The statistical significance of the interbreed differences of the remaining isomers is shown in Tables- 3 and 4.

Very important is the content of such FA as omega- 6 and omega- 3 in milk. In this regard, for a more detailed judgment of the share of the influence of the breed and seasons of the year, we conducted a two-factor analysis of variance. The results of the analysis are shown in Table-5. These tables also confirm the earlier conclusion that there was a noticeable breed influence $(\mathrm{p}<0.001)$ on milk quality.

\section{Discussion}

A component that is essential in the processing of milk into finished dairy products is milk fat. Fat is the most important quality and economic indicator of cow milk. On average, milk contains $3.7-3.8 \%$ fat with a significant variability [19]. The milk in our study corresponded to these averages at 3.7-4.0\%.
The number of somatic cells in milk is a relatively poorly studied indicator of safety, although it is clear that a reduced number of somatic cells improve milk quality. Studies have shown that the number of somatic cells in milk changes depending on calving season [20]. The largest number of somatic cells was found in the milk from spring calving cows (237 and $252 \times 10^{3} \mathrm{cells} / \mathrm{cm}^{3}$ ), which may be due to the extreme weather conditions. The smallest number of somatic cells occurs in summer calving cows ( 89 and $99 \times$ $10^{3}$ cells $/ \mathrm{cm}^{3}$ ). These results concur with those of our study, with 167.96 thousand somatic cells measured in $1 \mathrm{~cm}^{3}$.

The quantitative and qualitative FA composition changes slightly in each season. Gorelik et al. [21] found the lowest amount of conjugated acids in winter, and the highest amounts in summer, after which the amount gradually reduced. These changes are likely due to the presence of green fodder rich in easily digestible carbohydrates available to the cows in the summer but not the winter. 
Available at www.veterinaryworld.org/Vol.14/April-2021/21.pdf

Table-4: Fatty acid composition of milk in the autumn-winter period.

\begin{tabular}{|c|c|c|c|c|c|c|c|c|c|}
\hline \multirow[t]{2}{*}{ Fatty acid name } & $\overline{\boldsymbol{x}}$ & $\boldsymbol{m}_{\bar{x}}$ & $C v$ & $\overline{\boldsymbol{x}}$ & $\boldsymbol{m}_{\bar{x}}$ & $C v$ & \multicolumn{3}{|c|}{ Comparison of breeds } \\
\hline & \multicolumn{3}{|c|}{ Holstein } & \multicolumn{3}{|c|}{ Simmental } & $\boldsymbol{d}$ & $t_{d}$ & $\boldsymbol{p}$ \\
\hline \multicolumn{10}{|l|}{ Autumn } \\
\hline $\mathrm{C} 4: 0$ & 3.27 & 0.07 & 14.28 & 3.32 & 0.09 & 16.52 & 0.05 & 0.44 & $>0.05$ \\
\hline $\mathrm{C} 6: 0$ & 1.58 & 0.01 & 4.27 & 2.47 & 0.06 & 15.74 & 0.89 & 14.63 & $<0.001$ \\
\hline $\mathrm{C} 8: 0$ & 1.23 & 0.02 & 12.18 & 1.43 & 0.04 & 19.08 & 0.20 & 4.47 & $<0.001$ \\
\hline C10:0 & 2.08 & 0.01 & 2.62 & 3.03 & 0.09 & 18.50 & 0.95 & 10.49 & $<0.001$ \\
\hline C10:1 & 0.26 & 0.01 & 16.06 & 0.31 & 0.01 & 19.61 & 0.05 & 3.54 & $<0.001$ \\
\hline C12:0 & 2.71 & 0.06 & 15.12 & 3.75 & 0.07 & 12.05 & 1.04 & 11.28 & $<0.001$ \\
\hline C14:0 & 10.03 & 0.16 & 9.82 & 11.45 & 0.19 & 10.49 & 1.42 & 5.72 & $<0.001$ \\
\hline $\mathrm{C} 14: 1^{*}$ & 1.29 & 0.03 & 13.30 & 1.37 & 0.02 & 9.42 & 0.08 & 2.22 & $>0.05$ \\
\hline $\mathrm{C} 16: 0$ & 28.27 & 0.21 & 4.75 & 30.79 & 0.28 & 5.66 & 2.52 & 7.20 & $<0.001$ \\
\hline C16:1* & 2.09 & 0.05 & 13.89 & 2.38 & 0.01 & 1.40 & 0.29 & 5.69 & $<0.001$ \\
\hline C18:0 & 9.02 & 0.10 & 7.31 & 9.01 & 0.12 & 8.43 & 0.01 & 0.06 & $>0.05$ \\
\hline C18:1* & 29.25 & 0.23 & 5.04 & 22.69 & 0.25 & 7.07 & 6.56 & 19.31 & $<0.001$ \\
\hline C18:2* & 3.60 & 0.13 & 23.62 & 2.46 & 0.05 & 12.91 & 1.14 & 8.18 & $<0.001$ \\
\hline C18:3* & 1.01 & 0.05 & 33.37 & 0.67 & 0.04 & 36.17 & 0.34 & 5.31 & $<0.001$ \\
\hline C20:0 & 0.13 & 0.004 & 20.58 & 0.12 & 0.003 & 16.92 & 0.01 & 2.00 & $>0.05$ \\
\hline C22:0 & 0.07 & 0.002 & 20.11 & 0.07 & 0.003 & 27.84 & 0.00 & 0.00 & $>0.05$ \\
\hline Other & 4.09 & 0.05 & 7.96 & 4.67 & 0.08 & 10.98 & -0.58 & 6.15 & $<0.001$ \\
\hline \multicolumn{10}{|l|}{ Winter } \\
\hline C4:0 & 2.83 & 0.06 & 14.37 & 3.20 & 0.08 & 15.79 & 0.37 & 3.70 & $<0.001$ \\
\hline C6:0 & 1.78 & 0.04 & 12.63 & 1.59 & 0.02 & 7.61 & 0.19 & 4.25 & $<0.001$ \\
\hline C8:0 & 1.27 & 0.03 & 17.28 & 1.32 & 0.03 & 16.73 & 0.05 & 1.18 & $>0.05$ \\
\hline C10:0 & 2.93 & 0.08 & 17.79 & 2.01 & 0.02 & 5.06 & 0.92 & 11.16 & $<0.001$ \\
\hline C10:1 & 0.30 & 0.01 & 20.73 & 0.21 & 0.00 & 5.91 & 0.09 & 8.83 & $<0.001$ \\
\hline C12:0 & 3.31 & 0.09 & 17.72 & 2.50 & 0.06 & 15.73 & 0.81 & 7.49 & $<0.001$ \\
\hline C14:0 & 11.03 & 0.18 & 10.21 & 9.42 & 0.13 & 8.62 & 1.61 & 7.25 & $<0.001$ \\
\hline C14:1* & 1.12 & 0.03 & 19.21 & 1.40 & 0.01 & 6.57 & 0.28 & 8.85 & $<0.001$ \\
\hline C16:0 & 27.76 & 0.35 & 8.03 & 28.03 & 0.26 & 5.91 & 0.27 & 0.62 & $>0.05$ \\
\hline C16:1* & 2.08 & 0.04 & 11.90 & 1.55 & 0.01 & 3.78 & 0.53 & 12.85 & $<0.001$ \\
\hline C18:0 & 9.94 & 0.16 & 9.95 & 10.82 & 0.18 & 10.71 & 0.88 & 3.65 & $<0.001$ \\
\hline C18:1* & 26.17 & 0.32 & 7.73 & 28.91 & 0.26 & 5.68 & 2.74 & 6.65 & $<0.001$ \\
\hline C18:2* & 2.91 & 0.10 & 21.64 & 3.35 & 0.11 & 20.39 & 0.44 & 2.96 & $<0.01$ \\
\hline C18:3* & 0.80 & 0.04 & 34.38 & 1.17 & 0.04 & 22.17 & 0.37 & 6.54 & $<0.001$ \\
\hline C20:0 & 0.22 & 0.007 & 21.08 & 0.23 & 0.01 & 20.94 & 0.01 & 0.82 & $>0.05$ \\
\hline C22:0 & 0.09 & 0.003 & 19.46 & 0.10 & 0.003 & 22.34 & 0.01 & 2.36 & $>0.05$ \\
\hline Other & 5.47 & 0.09 & 10.76 & 4.19 & 0.05 & 7.75 & 1.28 & 12.43 & $<0.001$ \\
\hline
\end{tabular}

*The calculation is based on the sum of the isomers. by $v=40+40-2=78 t_{s t}=1.98(p=0.05)-2.63(p=0.01)-3.39$ $(p=0.001)$

Table-5: Two-factor analysis of variance.

\begin{tabular}{|c|c|c|c|c|c|c|}
\hline & A (breed) & B (season of the year) & $A B$ (the joint effect of) & $x$ & $z$ & $y$ \\
\hline \multicolumn{7}{|l|}{ C18:2 } \\
\hline$D$ & 154.01 & 18.36 & 143.76 & 316.14 & 518.55 & 834.69 \\
\hline$\eta$ & 0.18 & 0.02 & 0.17 & 0.38 & 0.62 & 1 \\
\hline$\sigma^{2}$ & 154.01 & 6.12 & 47.92 & 45.16 & 1.66 & 2.62 \\
\hline$F_{\text {emp }}$ & 92.67 & 3.68 & 28.83 & 27.17 & - & - \\
\hline$p^{e m p}$ & $<0.001$ & $<0.05$ & $<0.001$ & $<0.001$ & - & - \\
\hline \multicolumn{7}{|l|}{ C18:3 } \\
\hline$D$ & 98.62 & 49.20 & 813.90 & 961.72 & 972.37 & 1934.09 \\
\hline$\eta$ & 0.05 & 0.03 & 0.42 & 0.50 & 0.50 & 1 \\
\hline$\sigma^{2}$ & 98.62 & 16.40 & 271.30 & 137.39 & 3.13 & 6.08 \\
\hline$F_{\text {emp }}$ & 31.54 & 5.25 & 86.77 & 43.94 & - & - \\
\hline$p^{e m p}$ & $<0.001$ & $<0.01$ & $<0.001$ & $<0.001$ & - & - \\
\hline
\end{tabular}

Saturated FA (EFAS) dominates milk fat and ranges from $67.11 \%$ to $67.89 \%$, while unsaturated FA ranges from $31.8 \%$ to $32.16 \%$ [22]. Milk and dairy products are the most common source of conjugated linoleic acid. Two FAs linoleic acid (LA, C18:2 n-6) and $\alpha$-linoleic acid (ALA, C18:3n-3) are nutritionally important, since they cannot be synthesized by humans.
Human cells are included in this group along with other favorable FAs, such as conjugated linoleic acids [23]. In our studies, the content of EFAS ranged from $58.39 \%$ to $65.44 \%$ depending on the season and breed, and the content of monounsaturated FA ranged from $26.75 \%$ to $32.89 \%$ depending on season and breed. The PUFA content was highest in Holstein cows in the spring at 
$5.13 \%$, and the lowest in Simmental cows in the autumn at $-3.13 \%$. These data differ from the average literature values for other breeds, which had a high content of palmitic and stearic acids and a low content of polyunsaturated acids in winter, and a reverse trend in summer [2426]. This discrepancy may be due to changes in the diet during these periods and breed characteristics.

\section{Conclusion}

The physicochemical, microbiological parameters and biological value of milk from Simmental and Holstein cows in different lactation seasons were studied. Notable interbreed differences were found in the physicochemical and microbiological characteristics of milk (except for milk density from the summer period), with the Simmental breed superior to the Holstein breed in regard to the fat content and the number of somatic cells in milk. According to all the studied indicators (except for milk acidity), breed had a highly reliable effect on milk quality, but seasonal differences were random (except for milk density). The ratio of factorial variance to total variances ranged from 7.04 (somatic cell content) to $30.69 \%$ (milk density), in all cases $\mathrm{F}_{e m p}>\mathrm{F}_{s t}$. Statistically significant interbreed differences in FA (C6:0, C10:0, C14:0, C16:1, and C18:3) were also generally found. It is noteworthy that the mass fraction of caproic, caprylic, and capric FA in the spring-summer and winter periods was higher in the milk of Holstein cows and in the Simmental cows in the autumn. There were no noticeable interbreed differences in the sum of the isomers $\mathrm{C} 4: 0, \mathrm{C} 16: 0, \mathrm{C} 20: 0$, and $\mathrm{C} 22: 0$. In order to increase the concentration of the fat phase of milk and increase its biological value, it is necessary to optimize the diets of highly productive cows for all nutrients.

\section{Authors' Contributions}

AZK: Acquisition of data, analysis and interpretation of data, drafting the article, conception and design, revising it critically, and final approval. VSZ: Acquisition of data, analysis and interpretation of data, drafting the article, conception and design, revising it critically, and final approval. LAM: Acquisition of data, analysis and interpretation of data, drafting the article, conception and design, revising it critically, and final approval. ATK: Acquisition of data, analysis and interpretation of data, drafting the article, conception and design, revising it critically, and final approval. NZK: Acquisition of data, analysis and interpretation of data, drafting the article, conception and design, revising it critically, and final approval. KMM: Acquisition of data, analysis and interpretation of data, drafting the article, conception and design, and revising it critically. All authors have read and approved the final manuscript.

\section{Acknowledgments}

The research was carried out through self-financing. LLP "Kirova" and JSC "Astana-Onim" provided milk for this study. Kazakh National Agrarian Research University and LLP Kazakh Scientific Research Institute of Livestock and Fodder Production provided laboratory facilities for this study.

\section{Competing Interests}

The authors declare that they have no competing interests.

\section{Publisher's Note}

Veterinary World remains neutral with regard to jurisdictional claims in published institutional affiliation.

\section{References}

1. Heck, J.M., Van Valenberg, H.J., Dijkstra, J. and Van Hooijdonk, A.C. (2009) Seasonal variation in the Dutch bovine raw milk composition. J. Dairy Sci., 92(10): 4745-4755.

2. Dairy Co. (2013) Market Information, Supply and Production. Available from: http://www.dairyco.org.uk/ market-information/supply-production/composition-andhygiene/uk-milk-composition. Retrieved on 04-04-2013.

3. Chen, B., Lewis, M. and Grandison, A. (2014) Effect of seasonal variation on the composition and properties of raw milk destined for processing in the UK. Food Chem., 158: 216-223.

4. Quist, M.A., LeBlanc, S.J., Hand, K.J., Lazenby, D., Miglior, F. and Kelton, D.F. (2008) Milking-to-milking variability for milk yield, fat and protein percentage, and somatic cell count. J. Dairy Sci., 91(9): 3412-3423.

5. Pavel, E.R. and Gavan, C. (2011) Seasonal and milking to milking variations in cow milk fat, protein and somatic cell counts. Not. Sci. Biol., 3(2): 20-23.

6. Shulga, L.V. and Starovoytov, D.P. (2014) The influence of technology milking cows on the quality of milk. Sci. Notes UO VGAVM, 50(2): 342-345.

7. Gavrilova, N.B. and Schetinin, M.P. (2012) Technology of Milk and Dairy Products: Traditions and Innovations. Kolos, Moscow.

8. Parodi, P.W. (1999) Conjugated linoleic acid and other anticarcinogenic agents of bovine milk fat. J. Dairy Sci., 82(6): 1339-1349.

9. Chilliard, Y., Ferlay, A., Mansbridge, R.M. and Doreau, M. (2000) Ruminant milk fat plasticity: Nutritional control of saturated, polyunsaturated, trans and conjugated fatty acids. Ann. Zootech., 49(3): 181-205.

10. Chilliard, Y., Glasser, F., Ferlay, A., Bernard, L., Rouel, J. and Doreau, M. (2007) Diet, rumen biohydrogenation and nutritional quality of cow and goat milk fat. Eur. J. Lipid Sci. Technol., 109(8): 828-855.

11. Fievez, V., Colman, E., Montoya, J.C., Stefanov, I. and Vlaeminck, B. (2012) Milk odd-and branched-chain fatty acids as biomarkers of rumen function: An update. Anim. Feed Sci. Technol., 172(1-2): 51-65.

12. Shingfield, K.J., Bonnet, M. and Scollan N.D. (2013) Recent developments in altering the fatty acid composition of ruminant-derived foods. Animal, 7(Suppl 1): 132-162.

13. Van Haelst, Y.N.T., Beeckman, A., Van Knegsel, A.T.M. and Fievez, V. (2008) Short communication: Elevated concentrations of oleic acid and long-chain fatty acids in milk fat of multiparous subclinical ketotic cows. J. Dairy Sci., 91(12): 4683-4686.

14. Loften, J.R., Linn, J.G., Drackley, J.K., Jenkins, T.C., Soderholm, C.G. and Kertz, A.F. (2014) Invited review: Palmitic and stearic acid metabolism in lactating dairy cows. J. Dairy Sci., 97(8): 4661-4674.

15. Gorelik, O.V., Ryzhkova, A.V. and Omelkova, A. (2016) The Quality of the Milk of Cows Depends on the Age of the 
Cows. Youth and Science, 11: 1-6.

16. Rupp, R., Boichard, D., Bertrand, C. and Bazin, S. (2000) Overview of milk somatic cell counts in the French dairy cattle breeds. Prod. Anim., 13(4): 257-267.

17. State Standard 32915-2014 (2021) Milk and Dairy Products, Determination of Fatty Acid Composition of the Fatty Phase Using Gas Chromatography.

18. Abramova, N.I. and Serebrova, I.S. (2015) Effect of different milk production technology on milk yield of cows and somatic cell maintenance. Dairy Farm. J., 4(20): 7-12.

19. Loretts, O.G., Gorelik, O.V. and Neverova, O.P. (2019) Technological properties of milk depending on the season of the year. BIO, 1(220): 8-11.

20. Samusenko, L.D. and Khimicheva, S.N. (2018) The quality and safety of milk: The basis of food security. Bull. Agrar. Sci., 1(70): 46-51

21. Gorelik, O.V., Kharlap, S.Y., Temerbaeva, M.V. and Maksimyuk, N.N. (2020) Seasonal Changes in Milk Fat Characteristics in the Collection: Modern Trends in Scientific and Personnel Support of the Agro-industrial Complex.
Materials of the All-Russian Scientific-Practical Conference with International Participation, Conference. p230-234.

22. Khromova, L.G., Baylova, N.V. and Petrin, A.N. (2018) Fatty acid composition and biological value of milk of Holstein cows of different selection in adaptation period. Bull. Michurinsk State Agrar. Univ., 3: 81-87.

23. Fuke, G. and Nornberg, J. L. (2017) Systematic evaluation on the effectiveness of conjugated linoleic acid in human health. Crit. Rev. Food Sci. Nutr., 57(1): 1-7.

24. Samoylov, A.V., Kolpakov, E.Y., Suraeva, N.M., Petrov, A.N., Volodarskaya, T.K. and Goreva, T.A. (2017) Seasonal variations in fatty acids composition of cow's milk. Bull. KrasGAU, 9(132): 35-40.

25. Hanus, O., Krizova, L., Samkova, E., Spicka, J., Kucera, J., Klimesova, M., Roubal, P. and Jedelsk, R. (2016) The effect of cattle breed, season and type of diet on the fatty acid profile of raw milk. Arch. Anim. Breed., 59(3): 373-380.

26. Nategh, L., Yousefi, M., Zamani, E., Gholamian, M. and Mohammadzadeh, M. (2014) The effect of different seasons on the milk quality. Eur. J. Exp. Biol., 4(1): 550-552. 